thousand times more oestrogen than during the menstrual cycle. By the same token it may very well be that the livers of postmenopausal women are less well adapted to oestrogen inactivation than are those of women during the reproductive years; the evidence of altered liver function in post-menopausal women given oral contraceptives might for this reason be still less indicative of toxic change.

Finally, it may not be irrelevant that the majority of evidence suggesting a hepatotoxic effect of oral contraceptives has come from Finland. Such a geographical concentration may be not without significance, suggesting the local prevalence of disturbed hepatic function, a racial difference, or possibly one due to peculiarity of diet.

It is doubtful if any importance need be attached to the abnormal findings in the empirical tests. These tests merely reflect alterations in the plasma proteins, which, of course, are not necessarily the result of liver damage. Since oestrogens are known to increase the thyroid and cortisol-binding globulin of the plasma, for example, it is not surprising that these changes might lead to alterations in the results with the empirical tests. One of our patients (not included among those reported above), who had been treated with a number of different progestogens for many cycles (including Anovlar for 17 cycles) because of severe dysmenorrhœa, was found to have a positive cephalin cholesterol and thymol turbidity of 7 units (colloidal red negative). After stopping treatment for two cycles the results were unchanged, except that the colloidal red was now also positive. Three and a half months later the cephalin cholesterol was still weakly positive, the thymol turbidity was down to 2 units, and the colloidal red was negative. At this time the plasma bilirubin was $0.4 \mathrm{mg} . / 100 \mathrm{ml}$. (direct negative), P.G.O.T. 16 Karmen units, bromsulphthalein retention $2 \%$, and alkaline phosphatase 9.5 King-Armstrong units $/ 100 \mathrm{ml}$. We do not feel that the abnormal empirical test results in this patient were indicative of any liver damage.

\section{Summary}

No pathologically high values for glutamic oxalo-acetic acid transaminase, bromsulphthalein retention, or alkaline phosphatase were encountered in liver-function tests done on 12 women aged 29-42 who have been using oral contraceptives for three to six years continuously. One of these patients had a plasma bilirubin of $1.7 \mathrm{mg} . / 100 \mathrm{ml}$. (normal upper limit 0.8 $\mathrm{mg} . / 100 \mathrm{ml}$.) and one a doubtfully high transaminase of 38
Karmen units, but the other parameters were normal. Some abnormal results in empirical liver-functions tests (cephalin cholesterol, colloidal red, and thymol turbidity) were obtained, but reasons are advanced for doubting whether these are indicative of any hepatotoxic effects.

Our thanks are due to Dr. G. R. Daniel, of John Wyeth and Brother Ltd. ; to Dr. A. David, of British Drug Houses Ltd. ; to Dr. Jürgen Friebel, of Schering, A.G. ; to Dr. N. W. Shephard, of Ortho Pharmaceuticals Ltd. ; to Dr. W. J. Tindall, of Organon Laboratories Ltd. ; and Dr. G. R. Venning, of G. D. Searle \& Co. Ltd., for the generous supplies of oral contraceptives used by the patients mentioned in this report.

AdDENDUM.-Since submitting this paper a number of additional relevant reports have appeared. Bakke (1965) could find no evidence of hepatic impairment in 36 menopausal women, aged 42-77 years, taking mestranol $0.075 \mathrm{mg}$. daily, either alone or in combination with norethynodrel $5 \mathrm{mg}$. The duration of treatment at the time of testing was 1 to 24 months (mean 8.76 months). This work, reported from Seattle, is thus completely at variance with the Finnish findings. However, from Uppsala, Sweden, Cullberg et al. (1965) describe a case of jaundice which developed within a month of taking Lyndiol for about 14 days. Liver biopsy showed intrahepatic cholestasis and hepatocellular damage. These authors suspect that the oral contraceptive was responsible for the development of the jaundice but state : "It should be remembered ... that in the present case and in the solitary cases [mentioned in their paper] the relation between jaundice and drug is not unquestionable." Stoll et al. (1965), in Melbourne, treated four post-menopausal patients with cancer of the breast with six tablets of Lyndiol daily-that is, six times the normal dose-and in all cases found raised S.G.O.T. and serum isocitric dehydrogenase levels. Clinical jaundice was seen in two patients with serum bilirubin levels of up to $41 \mathrm{mg}$./ $100 \mathrm{ml}$. Liver biopsy in all four patients showed centrilobar parenchyma cell necrosis and, in the two with jaundice, cholestasis in the hepatic cells and biliary canaliculi.

\section{REFERENCES}

Adlercreutz, H., and Ikonen, E. (1964). Brit. med. F., 2, 1133.

Bakke, J. L. (1965). Ibid., 1. 631.

Cullberg, G., Lundström, R., and Stenram, U. (1965). Ibid., 1, 695.

Eisalo, A., Järvinen, P. A., and Luukkainen, T. (1964). Ibid., 2, 426.

Eisalo, A., Jarvinen, P. A., and Luuk

Palva, I. P., and Mustala, O.. Ó. (1964). Ibid., 2, 688.

Rice-Wray, E. (1964). Ibid., 2, 1011.

Sotaniemi, E., Kreus, K. E., and Scheinin, T. M. (1964). Ibid., 2, 1264. Stoll, B. A., Andrews, J. T., Motteram, R., and Upfill, J. (1965). Ibid., 1, 723.

Swaab, L. I. (1964). Ibid., 2, 755

Tyler, E. T. (1964a). Ibid., 2, 843.

(1964b). Ibid., 2, 1264 .

\title{
Oral Contraception and Liver-function Tests
}

\author{
ULF LARSSON-COHN,* M.D.
}

Brit. med. F., 1965, 1, 1414-1415

Certain C $17 \alpha$-alkyl substituted testosterones, in particular methyltestosterone (Foss and Simpson, 1959 ; Petersen, 1963), norethandrolone (Nilevar) (Gordon et al., 1962; Shaw and Gold, 1960), and methandienone (Dianabol) (Kaupp and Preston, 1962 ; Wilder, 1962 ; Petersen, 1963), have been shown to be capable of affecting the excretory function of the liver. In a more recent study (Mueller and Kappas, 1964) high doses of natural oestrogens were found to increase bromsulphthalein retention in 28 out of 31 patients.

- Gynaecological Department, Akademiska Sjukhuset, Uppsala, Sweden.
Most oral contraceptive preparations contain a small amount of oestrogen combined with a C $17 \alpha$-alkyl substituted progestogenic steroid. In spite of this, there have been few reports of liver damage or abnormal liver-function tests. In two reports from Finland (Eisalo et al., 1964 ; Palva and Mustla, 1964) a small group of post-menopausal women given Anovlar (norethisterone acetate $4 \mathrm{mg}$. and ethinyloestradiol, $0.05 \mathrm{mg}$.) or Lyndiol (ethynyloestrenol $5 \mathrm{mg}$. and ethinyloestradiol-3methylether (mestranol; $\mathrm{EO}^{3} \mathrm{ME}$ ) $0.15 \mathrm{mg}$.), showed a considerable rise in serum transaminase levels. Furthermore, Tyler (1964), in a series of 214 women who were given a combination 
of either norethindrone $10 \mathrm{mg}$. and mestranol $0.06 \mathrm{mg}$. or norethindrone $2 \mathrm{mg}$. and mestranol $0.1 \mathrm{mg}$., found increased bromsulphthalein retention in $21-38 \%$. Other authors (Linthorst, 1964 ; Rice-Wray, 1964 ; Swaab, 1964), on the other hand, found no abnormal liver-function tests in patients taking various oral contraceptive preparations.

\section{Material and Method}

A preparation containing norethindrone $2 \mathrm{mg}$. and mestranol $0.1 \mathrm{mg}$. was given to 284 women aged 18-46 years (mean 27.8) for contraception (Larsson-Cohn, 1964). After the first six months the dose of mestranol was reduced to $0.075 \mathrm{mg}$. One tablet was given daily from the fifth to the twenty-fourth day of each menstrual cycle.

A year later the levels of glutamic oxaloacetic transaminase (S.G.O.T.), glutamic pyruvic transaminase (S.G.P.T.), bilirubin, and alkaline phosphatase and the thymol turbidity were estimated in the majority of the women who remained in the trial. The bromsulphthalein retention was estimated in a few cases.

\section{Results}

The incidence of abnormal results is shown in Table I and the cases with raised levels of S.G.O.T., S.G.P.T., and serum alkaline phosphatase are listed in Table II and III.

TABLB I.-Incidence of Abnormal Results of Liver-function Tests

\begin{tabular}{|c|c|c|c|}
\hline Test (Normal Values) & & $\begin{array}{l}\text { No. of } \\
\text { Subjects }\end{array}$ & $\begin{array}{l}\text { No. with } \\
\text { Abnormal } \\
\text { Results }\end{array}$ \\
\hline 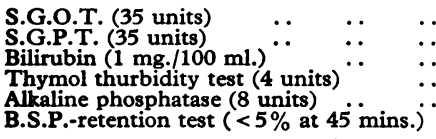 & $\begin{array}{l}\because \\
\because \\
\because \\
\therefore\end{array}$ & $\begin{array}{r}243 \\
243 \\
202 \\
202 \\
199 \\
12\end{array}$ & $\begin{array}{r}14(5 \cdot 8 \%) \\
18(7 \cdot 4 \%) \\
0(10 \cdot 9 \%) \\
22(10 \%) \\
4(2 \%) \\
5(41 \cdot 6 \%)\end{array}$ \\
\hline
\end{tabular}

TABLE II.-Raised Levels of S.G.O.T. and S.G.P.T. (Units)

\begin{tabular}{|c|c|c|c|c|c|c|c|}
\hline $\begin{array}{l}\text { Case } \\
\text { No: }\end{array}$ & $\begin{array}{l}\text { First } \\
\text { Test }\end{array}$ & $\begin{array}{c}\text { Second } \\
\text { Test }\end{array}$ & $\begin{array}{l}\text { Third } \\
\text { Test }\end{array}$ & $\begin{array}{l}\text { Case } \\
\text { No. }\end{array}$ & $\begin{array}{l}\text { First } \\
\text { Test }\end{array}$ & $\begin{array}{c}\text { Second } \\
\text { Test }\end{array}$ & $\begin{array}{l}\text { Third } \\
\text { Test }\end{array}$ \\
\hline $\begin{array}{r}35 \\
37 \\
44 \\
95 \\
97 \\
130 \\
145 \\
150 \\
158 \\
159 \\
174 \\
231 \\
236 \\
267\end{array}$ & $\begin{array}{l}40 \\
32 \\
25 \\
56 \\
55 \\
30 \\
35 \\
26 \\
35 \\
55 \\
35 \\
20 \\
45 \\
50\end{array}$ & $\begin{array}{l}50 \\
36 \\
40 \\
35 \\
20 \\
52 \\
82 \\
24 \\
20 \\
12 \\
50 \\
20 \\
75\end{array}$ & $\begin{array}{l}35 \\
34 \\
23 \\
75 \\
40 \\
42 \\
49 \\
49\end{array}$ & $\begin{array}{r}30 \\
37 \\
82 \\
90 \\
95 \\
97 \\
101 \\
130 \\
145 \\
150 \\
158 \\
159 \\
174 \\
229 \\
231 \\
236 \\
240 \\
269\end{array}$ & $\begin{array}{r}50 \\
42 \\
14 \\
48 \\
140 \\
100 \\
35 \\
24 \\
56 \\
55 \\
45 \\
65 \\
40 \\
70 \\
12 \\
55 \\
38 \\
68\end{array}$ & $\begin{array}{r}24 \\
55 \\
38 \\
24 \\
38 \\
20 \\
38 \\
92 \\
140 \\
24 \\
20 \\
20 \\
26 \\
14 \\
24 \\
24 \\
80\end{array}$ & $\begin{array}{r}50 \\
15 \\
25 \\
\\
110 \\
72 \\
42\end{array}$ \\
\hline
\end{tabular}

TABLE III.-Raised Serum Levels of Alkaline Phosphatase (Units)

\begin{tabular}{|c|c|c|c|c|c|c|}
\hline \multicolumn{4}{|c|}{ Case No. } & First Test & Second Test & Third Test \\
\hline $\begin{array}{r}37 \\
130 \\
190 \\
260\end{array}$ & $\begin{array}{l}\ldots \\
\because \\
\end{array}$ & $\begin{array}{c}\cdots \\
\cdots \\
\cdots\end{array}$ & $\begin{array}{l}\ldots \\
\therefore\end{array}$ & $\begin{array}{r}8.7 \\
5.7 \\
16.8 \\
11.2\end{array}$ & $\begin{array}{l}6 \cdot 3 \\
9 \cdot 6 \\
2 \cdot 3 \\
7 \cdot 4\end{array}$ & $9 \cdot 0$ \\
\hline
\end{tabular}

Case 130.-A woman aged 36 became mildly jaundiced after taking the tablets for 11 months and was admitted to another hospital. The serum bilirubin was $2 \mathrm{mg} . / 100 \mathrm{ml}$., S.G.O.T. 168 u./100 ml. and S.G.P.T. $100 \mathrm{u} . / 100 \mathrm{ml}$. Within four days, in spite of continued medication, all the values returned to normal and the tests were repeated here two and four months later. There was no evidence that she had had infectious hepatitis, and serum hepatitis was thought unlikely to have been the cause of her jaundice, which has therefore been attributed to the contraceptive tablets.

As seen in Table $I$, the incidence of abnormal thymol turbidity was relatively high, but when this test was repeated in 13 cases it was found to be normal in eight. The B.S.P. retention was estimated in 12 cases and found to be increased in five of them but never to more than $9.2 \%$.

\section{Discussion}

The incidence of abnormal liver-function tests in this series is high compared with most other reports. Although there has been no evidence of any serious impairment of liver function with norethindrone $2 \mathrm{mg}$. and mestranol $0.075 \mathrm{mg}$. it is difficult to rule out the possibility that this preparation is hepatotoxic.

A study is now in progress in which the serum transaminase levels are estimated at regular intervals in a large number of women using various oral contraceptive preparations. The incidence of abnormal results is not negligible and varies with the preparations. The preliminary results indicate that serum transaminase levels rapidly return to normal when medication is stopped. Furthermore, it is not uncommon for the levels to fall during that part of the menstrual cycle in which the tablets are omitted.

\section{Summary}

Liver-function tests were carried out in 243 women aged 18-46 years who for a period 6 to 18 months had received a combination of norethindrone $2 \mathrm{mg}$. and mestranol $0.075 \mathrm{mg}$. for contraception. Bromsulphthalein retention was increased in $42 \%$ of cases, thymol turbidity in $11 \%$, S.G.P.T. in $7 \%$, S.G.O.T. in $6 \%$, and serum alkaline phosphatase in $2 \%$. Jaundice occurred in one case but subsided within four days in spite of continued medication.

The tests were performed at the Chemical Laboratory of the County Hospital, Eskilstuna. I wish to thank Professor G. Brante and his assistants for all their help.

\section{REFERENCES}

Eisalo, A., Järvinen, P. A., and Luukkainen, T. (1964). Brit. med. J., $2,426$.

Foss, G. L., and Simpson, S. L. (1959). Brit. med. F., 1, 259.

Gordon, B. S., Wolf, J., Krause, T., and Shai, F. (1960). Amer. 7. clin. Path., 33, 156.

Kaupp, H. A., and Preston, F. W. (1962). f. Amer. med. Ass., 180, 411.

Larsson-Cohn, U. (1964). Svenska Läk.-Tidn., 61, 1328.

Linthorst, G. (1964). Brit. med. F., 2, 920.

Mueller, M. N., and Kappas, A. (1964). F. clin. Invest., 43, 1905.

Palva, I. P., and Mustala, O. O. (1964). Brit. med. F., 2, 688

Petersen, K. E. (1963). Ugeskr. Lag., 125, 421.

Rice-Wray, E. (1964). Brit. med. F., 2, 1011.

Shaw, R. K., and Gold, G. L. (1960). Ann. intern. Med., 52, 428.

Swaab, L. I. (1964). Brit. med. F., 2, 755.

Tyler, E. T. (1964). Appl. Ther., 6, 507.

Wilder, E. M. (1962). Canad. med. Ass. f., 87, 768. 